\title{
分散粒子を含まない溶液からの高流速撹拌下における $\mathrm{Zn}-\mathrm{V}$ 酸化物複合電析
}

\author{
中野 博昭 ${ }^{1) *} \cdot$ 大上 悟 $^{1)} \cdot$ 案浦 康徳 $^{2)} \cdot$ 永井 啓明 ${ }^{3)} \cdot$ 大穂 元人 ${ }^{4)} \cdot$ 福島 久哲 ${ }^{5)}$
}

Electrodeposition of Zn-V Oxide Composite from Strong Agitated Solution without Dispersed Particles

Hiroaki Nakano, Satoshi Oue, Yasunori Annoura, Takaaki Nagai, Naoto Oho and Hisaaki Fukushima

Synopsis : Electrodeposition of $\mathrm{Zn}-\mathrm{V}$ oxide composite was examined from an agitated sulfate solution without dispersed particles containing $\mathrm{Zn}^{2+}$ and $\mathrm{VO}^{2+}$ at $\mathrm{pH} 2$ and $40{ }^{\circ} \mathrm{C}$ under galvanostatic conditions. Although $\mathrm{V}$ content in deposits decreased for the moment with increasing current density regardless of flow rate of electrolyte, the further increase in current density brought about the increase in $\mathrm{V}$ content in deposits. The curves, which shows the relationship between the $\mathrm{V}$ content in deposits and current density, shifted to the higher current density region with increasing flow rate of electrolyte. Agitation of the electrolyte decreased the $\mathrm{V}$ content of the deposits but reduced the segregation of $\mathrm{V}$ oxide. EDX point analysis of cross section of deposits revealed that the $\mathrm{V}$ oxide concentrated at the surface of deposits. It was found from the polarization curves in $3 \% \mathrm{NaCl}$ solution that the corrosion potential of deposited $\mathrm{Zn}-\mathrm{V}$ oxide films depended on the $\mathrm{V}$ content in deposits regardless of the flow rate of electrolyte and it shifted to more noble direction with codeposition of $\mathrm{V}$ oxide at $\mathrm{V}$ contents in deposits below 2 mass $\%$. At $\mathrm{V}$ contents of $<4$ mass $\%$, the corrosion current density of deposits decreased with increasing $\mathrm{V}$ contents in deposits. The corrosion current densities of deposits obtained from agitated solutions were smaller than that from un-agitated solutions.

Key words : electrodeposition; $\mathrm{Zn}$ with V oxide; polarization curve; corrosion potential; corrosion current density; composite; agitate; dispersed particle.

\section{1. 緒言}

高耐食性薄目付けの Zn 系電析膜の共析元素としては, ドライプロセスで作製された Zn系合金膜の調査結果か ら $\mathrm{Mg}, \mathrm{Al}, \mathrm{Ti}$ などの標準単極電位が Znより卑な活性金属 が有望である ${ }^{1-10)}$ 。Vもその標準単極電位がー $1.186 \mathrm{~V}$ (vs. $\mathrm{NHE})$ と $\mathrm{Zn}(-0.76 \mathrm{~V})$ より卑な活性金属の一種であり, $\mathrm{Zn}$ 膜中にVを含有させれば耐食性の改善が期待される。そ こで著者らは, $\mathrm{Zn}^{2+} よ り$ 低い $\mathrm{pH}$ で加水分解する $\mathrm{VO}^{2+}$ 電 解液に添加し，静止浴で $\mathrm{Zn}-\mathrm{V}$ 系電析の検討を行ない，その 電析挙動と得られた電析膜の構造, 分極特性を前報にて報 告した ${ }^{11)}$ 。 $\mathrm{V}$ は $\mathrm{VO}^{2+}$ の加水分解反応により酸化物の形で電 析膜に取り込まれ, Zn 板状結晶のエッジ部に偏析している ことが分かった。

一方, $\mathrm{Zn}$ 系の合金電析においては, 液流速により各合金 元素の拡散限界電流密度が変化することにより, 合金組 成, 電流効率, 表面外観等が大きな影響を受けることが報 告されている ${ }^{12-15)}$ 。本研究の Zn-V系電析においても高流 速擋找下で電析を行えば，その電析挙動，V酸化物の分布
状態, 分極特性は液流速の影響を受けることが予想され る。そこで本研究では, 高流速擋拌下において, Zn-V酸化 物複合電析の検討を行なった。本研究では電析を行う際, 円柱状の陰極を回転させて陰極表面の相対液流速を変化さ せた。V酸化物の共析に及ぼす電流密度, 液流速の影響を 調べた。また, $\mathrm{V}$ 酸化物を含有した電析 Zn 膜中の V の分布 状態および分極特性を調べた。

\section{2. 実験方法}

電解液組成および電解条件を Table 1 に示す。電解液は 市販の特級試薬を用い, $\mathrm{ZnSO}_{4} \cdot 7 \mathrm{H}_{2} \mathrm{O} 0.52 \mathrm{~mol} / \mathrm{L}, \mathrm{VOSO}_{4}$ • $5 \mathrm{H}_{2} \mathrm{O} 0.21 \mathrm{~mol} / \mathrm{L}$ を純水に溶解させて作製した。 $\mathrm{pH}$ は硫酸 により 2.0 に調整した。電析は, Fig.1に示すような円柱状の $\mathrm{Cu}$ 陰極 ( $\phi 4 \mathrm{~cm}$, 長さ $\left.2 \mathrm{~cm}, 25.1 \mathrm{~cm}^{2}\right)$ をテフロンリングで 固定し, 速度 500, 1000, 2000, $3000 \mathrm{rpm}$ で回転させながら, 定電流電解法で電流密度 500 $7000 \mathrm{~A} / \mathrm{m}^{2}$, 通電量 $10^{5} \mathrm{C} / \mathrm{m}^{2}$,

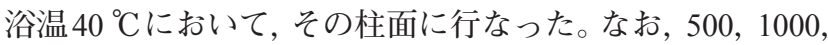
2000，3000 rpmは，それぞれ陰極面に対する液の相対流速

平成 25 年 7 月 18 日受付 平成 25 年 10 月24日受理 (Received on Jul. 18, 2013 ; Accepted on Oct. 24, 2013)

1）九州大学大学院工学研究院 (Faculty of Engineering, Kyushu University, 744 Motooka Nishi-ku Fukuoka-shi 819-0395)

2）九州大学大学院工学府 (現 : 日本タングステン (株)) (Graduate School of Engineering, Kyushu University, now NIPPON TUNGSTEN CO., LTD.)

3) 九州大学大学院工学府 (現 : 住友金属鉱山 (株)) (Graduate School of Engineering, Kyushu University, now SUMITOMO METAL MINING CO., LTD.)

4）九州大学大学院工学府 (Graduate School of Engineering, Kyushu University)

5) 九州大学大学院工学研究院 (Faculty of Engineering, Kyushu University)

* Corresponding author : E-mail : nakano@zaiko.kyushu-u.ac.jp

DOI : http://dx.doi.org/10.2355/tetsutohagane.100.376 
が 1.1, 2.1, 4.2, $6.3 \mathrm{~m} / \mathrm{s}$ に相当し, 以下本論文では, 擋找の 程度は相対流速で表示する。陽極にはPtめっきを施した網 状 Ti を用い，陰極の周囲に配置した。電解の際，陽極にお いて $\mathrm{VO}^{2+}$ が $\mathrm{V}_{2} \mathrm{O}_{5}$ に酸化されるため, 陽極室と陰極室を和 紙のフィルターで隔離した電解槽を用いた。得られた電析 膜は硝酸で溶解し, ICP 発光分光分析法により Zn, Vを定 量し, 電析合金組成, $\mathrm{Zn}$ 電析の電流効率を求めた。

電析膜の表面, 断面形態, 元素分布は, 極低加速電圧 SEM (Carl Zeiss Ultra55), EPMA おょよびEDXにより調べ た。電析膜の Zn の結晶配向性をX 線回折装置 $(\mathrm{Cu}-\mathrm{K} \alpha$, 管 電圧 $40 \mathrm{kV}$, 管電流 $20 \mathrm{~mA}$ ) により測定した。Znの結晶配 向性は 0002 から $11 \overline{2} 2$ 反射のX線回折強度を測定した後, Willson と Rogersの方法 ${ }^{16)}$ で求めた配向指数により表示し た。電解液の加水分解挙動を調べるため, $\mathrm{NaOH}$ を用いて $\mathrm{pH}$ 滴定曲線を測定した。各々 $0.05 \mathrm{~mol} / \mathrm{L}$ の $\mathrm{ZnSO}_{4}$ と $\mathrm{VOSO}_{4}$ の混合液およびそれぞれの単独液にビュレットを用いて $5.0 \mathrm{~N}$ の $\mathrm{NaOH}$ を滴定した。混合液については, 滴定途中の 溶液中の $\mathrm{Zn}^{2+}, \mathrm{VO}^{2+}$ 濃度を ICP 発光分光分析法により測定 した。また, 電解時の水素発生による陰極近傍の $\mathrm{pH}$ 変化を 調べるために, 微小 $\mathrm{Sb}$ 電極 ${ }^{17)}$ を作製した。実験は, 静止液 に打いて $200 \mathrm{~A} / \mathrm{m}^{2}$ で電解する際，マイクロメータに取り付 けた微小 Sb電極を陰極面に接触するまで近づけ，陰極か ら所定の距離における $\mathrm{Sb}$ 電極の電位を測定した。測定前 にあらかじめ求めた電解液の $\mathrm{pH}$ と $\mathrm{Sb}$ 電極の電位との関係 $(\mathrm{pH}$ 一電位校正曲線) を利用して, 電解時における陰極層 の $\mathrm{pH}$ を求めた。

電析膜の耐食性は分極曲線により評価した。分極曲線

Table 1. Electrolysis conditions.

\begin{tabular}{l|ll}
\hline \multirow{3}{*}{ Bath composition } & $\mathrm{ZnSO}_{4} \cdot 7 \mathrm{H}_{2} \mathrm{O}(\mathrm{mol} / \mathrm{L})$ & 0.52 \\
& $\mathrm{VOSO}_{4} \cdot 5 \mathrm{H}_{2} \mathrm{O}(\mathrm{mol} / \mathrm{L})$ & 0.21 \\
& $\mathrm{pH}$ & 2 \\
\hline & Current density $\left(\mathrm{A} / \mathrm{m}^{2}\right)$ & $500 \sim 7000$ \\
& Amount of charge $\left(\mathrm{C} / \mathrm{m}^{2}\right)$ & $10^{5}$ \\
\multirow{3}{*}{ Operating conditions } & Temperature $\left({ }^{\circ} \mathrm{C}\right)$ & 40 \\
& Cathode & $\mathrm{Cu}(\varphi 4 \mathrm{~cm} \times 2 \mathrm{~cm})$ \\
& Anode & $\mathrm{Pt} / \mathrm{Ti}$ \\
& Flow rate $(\mathrm{m} / \mathrm{s})$ & $1.1 \sim 6.3$ \\
\hline
\end{tabular}

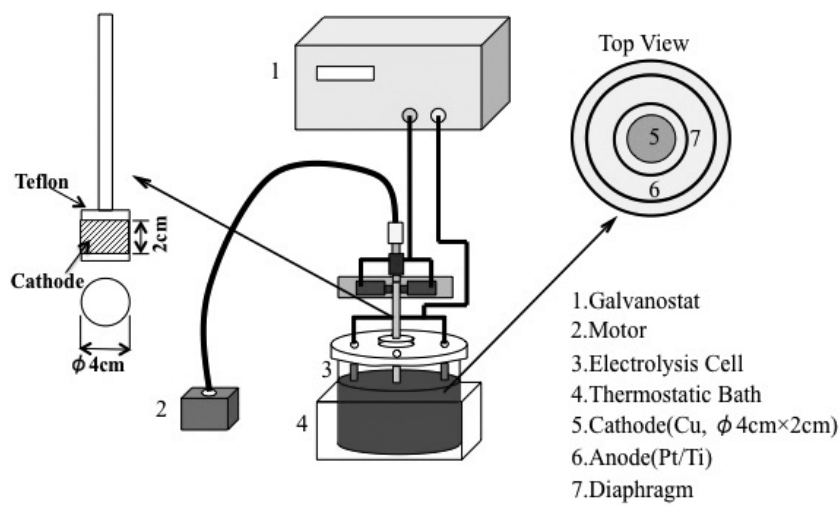

Fig. 1. Apparatus for electrolysis.
は，酸素を飽和させた $40{ }^{\circ} \mathrm{C}, 3 \% \mathrm{NaCl}$ 水溶液中において, 電位掃引法により $1.0 \mathrm{mV} / \mathrm{s}$ の速度で卑な電位から貴な電位 に移行させて測定した。この分極曲線よりターフェル外挿 法により腐食電流密度と腐食電位を求めた。分極曲線を測 定する際，参照電極として $\mathrm{Ag} / \mathrm{AgCl}$ 電極 (0.199 Vvs. NHE, $\left.25{ }^{\circ} \mathrm{C}\right)$ を使用したが, 電位は標準水素電極基準に換算して 表示した。

\section{3. 結果および考察}

\section{$3 \cdot 1 \mathrm{~V}$ の形態, 平衡電位}

Fig.2 に V- $\mathrm{H}_{2} \mathrm{O}$ 系の電位 $\mathrm{pH}$ 図を示す。溶液中のV濃度は $0.8 \mathrm{~mol} / \mathrm{L}$ であり, Vイオンの活量係数は 1 と仮定した。使

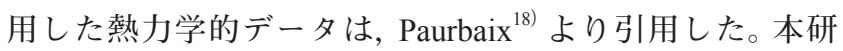
究で使用した $\mathrm{pH} 2$ の電解液では, $\mathrm{V} は \mathrm{VO}^{2+}$ として存在する が, $\mathrm{pH}$ が 2.38 より高くなると, $\mathrm{VO}^{2+}$ は加水分解反応を起 こし $\mathrm{V}_{2} \mathrm{O}_{4}$ が安定となる。水溶液からの $\mathrm{Zn}$ 電析では, 陰極 に打いて水素が発生するため, 陰極界面の $\mathrm{pH}$ が上昇する。 この $\mathrm{pH}$ が加水分解反応を起こす臨界值を越えると陰極界 面では $\mathrm{VO}^{2+}$ イオンは加水分解反応により $\mathrm{V}_{2} \mathrm{O}_{4}$ 酸化物とし て安定に存在することが予想される。

\section{$3 \cdot 2 \mathrm{~V}$ 酸化物の共析挙動}

Fig. 3 に電析膜のV含有率に及ぼす電流密度, 電解液流 速の影響を示す。なお, 本論文に打ける電析膜のV含有 率 $(\mathrm{mass} \%)$ は, 電析膜の $\mathrm{V}, \mathrm{Zn}$ 濃度より $[\mathrm{V} /(\mathrm{Zn}+\mathrm{V})] \times$ 100 により算出したものである。電析膜の $\mathrm{V}$ 含有率は, 何 れの流速に打いても電流密度が高くなるほど一旦減少し, 更に電流密度が高くなると増加に転じた。高電流密度の領 域に打いて, 電流密度が高くなるほど電析膜のV含有率が 増加したのは, 電流密度の増加に伴い水素発生速度が速く なり陰極界面で $\mathrm{pH}$ が上昇し $\mathrm{VO}^{2+}$ イオンが加水分解し易く なるためと考えられる。次に, 流速の影響に着目すると，

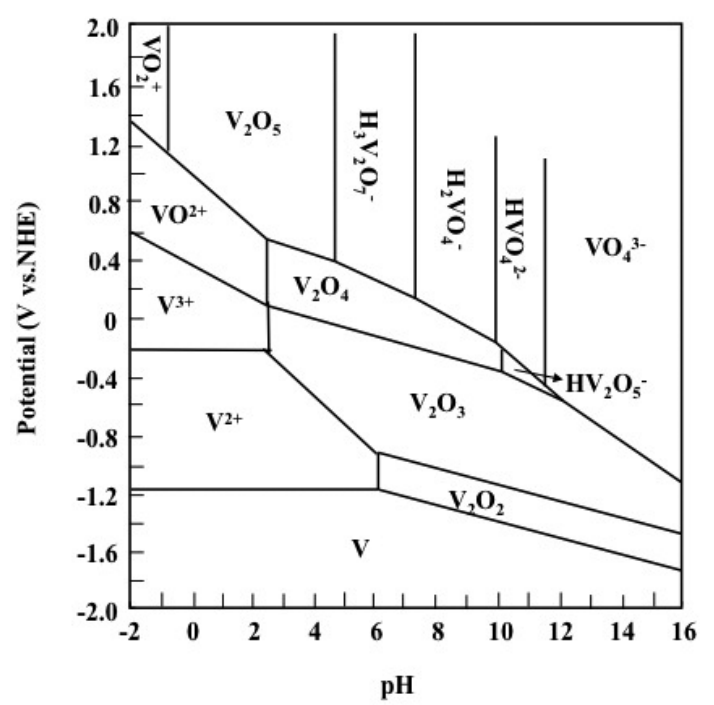

Fig. 2. Potential-pH diagram for $\mathrm{V}-\mathrm{H}_{2} \mathrm{O}$ system at $25^{\circ} \mathrm{C} .\left(\mathrm{a}_{\mathrm{v}}=0.8\right)$ 
流速が速くなるほど, 電析膜の V 含有率と電流密度の関係 を示す曲線が高電流密度側にシフトすることが分かった。 高電流密度の領域に打いては, 電析膜のV含有率は, 流速 が速くなると低下した。これは，流速が速くなると陰極界 面への $\mathrm{H}^{+}$の拡散が促進されるため, 陰極界面の $\mathrm{pH}$ が上昇 し難くなり, すなわち, $\mathrm{VO}^{2+}$ イオンの加水分解が起こり難 くなるためと考えられる。

Fig.4にZn-V複合電析における Znの電流効率に及ぼす電 流密度と流速の影響を示す。Zn析出の電流効率は，何れの 流速に打いても, 電流密度が高くなるほど增加し, 最大值 を示した後, 更に電流密度が高くなると低下した。低電流 密度の領域で, 電流密度が高くなるほど Zn析出の電流効 率が増加したのは, Zn電析の過電圧が増加するためであ り, 高電流密度域で, 電流密度が高くなるほど Znの電流効 率が低下したのは $\mathrm{Zn}^{2+}$ イオンの拡散限界に到達したためと 考えられる。次に，流速の影響を見ると，流速が速くなる ほど, $\mathrm{Zn}$ 析出の電流効率と電流密度の関係を示す曲線は高 電流密度側にシフトし, 全電流密度域に打いて流速が速く なるほどZn析出の電流効率は低下した。流速が速くなる ほど $\mathrm{H}^{+}$イオンの拡散が促進されるため, $\mathrm{Zn}$ 析出の電流効

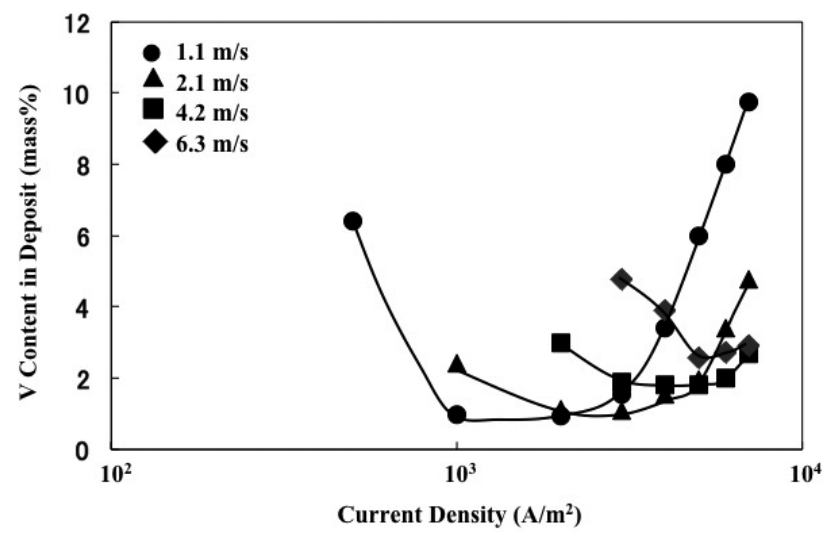

Fig. 3. Effect of current density and flow rate on the $\mathrm{V}$ content in deposit.
率は低下したと考えられる。また，高電流密度域では，流 速が速くなるとZnの電流効率が低下し始める電流密度が 高電流密度側にシフトしたが, これは, 流速が速くなるほ ぞ, $\mathrm{Zn}^{2+}$ イオンの拡散限界に到達し難くなるためと考元ら れる。ところで, Fig.3に示すように低電流密度域では，何 れの流速に打いても電流密度が低下するほどV含有率が増 加したが，これは，Fig.4に示すように電流密度が低下する ほどZnの電流効率が低下したためと考えられる。

$\mathrm{VO}^{2+}, \mathrm{Zn}^{2+}$ 含む溶液からの電析では, 水素発生により 陰極近傍の $\mathrm{pH}$ が上昇し, 加水分解反応により金属酸化物 が生成される。 $\mathrm{V}_{2} \mathrm{O}_{4}$ 生成の臨界 $\mathrm{pH}$ は, その溶解度積 $10^{-23.1}$

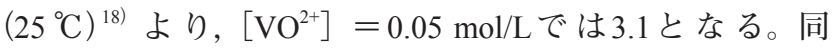
様に, $\mathrm{Zn}(\mathrm{OH})_{2}$ 生成の臨界 $\mathrm{pH}$ は, その溶解度積 $2 \times 10^{-17}$ $\left(25^{\circ} \mathrm{C}\right)^{19)}$ より, $\left[\mathrm{Zn}^{2+}\right]=0.05 \mathrm{~mol} / \mathrm{L}$ では 6.3 である。

Fig. 5 に $\mathrm{Zn}^{2+}, \mathrm{VO}^{2+}$ を含む溶液に 5 規定の $\mathrm{NaOH}$ 溶液を滴 定した際の $\mathrm{pH}$ 変化を示す。 $\mathrm{Zn}^{2+}$ のみを含む溶液では $\mathrm{pH} 6.5$ 付近で, $\mathrm{VO}^{2+}$ のみを含む溶液では $\mathrm{pH} 4$ 付近で $\mathrm{pH}$ の上昇が 停滞すると同時に溶液が懸濁し沈殿が生成し始めた。 $\mathrm{Zn}^{2+}$ と $\mathrm{VO}^{2+}$ をもに含む溶液では, $\mathrm{pH} 4$ と 6.5 付近で, $\mathrm{pH}$ の上 昇が停滞しており, $\mathrm{Zn}^{2+}$ のみまたは $\mathrm{VO}^{2+}$ のみを含む溶液か

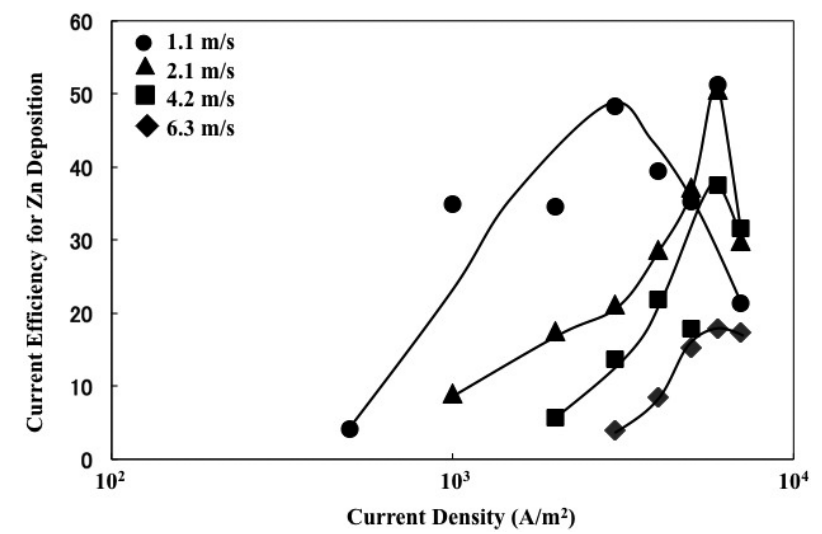

Fig. 4. Effect of current density and flow rate on the current efficiency for $\mathrm{Zn}$ deposition.

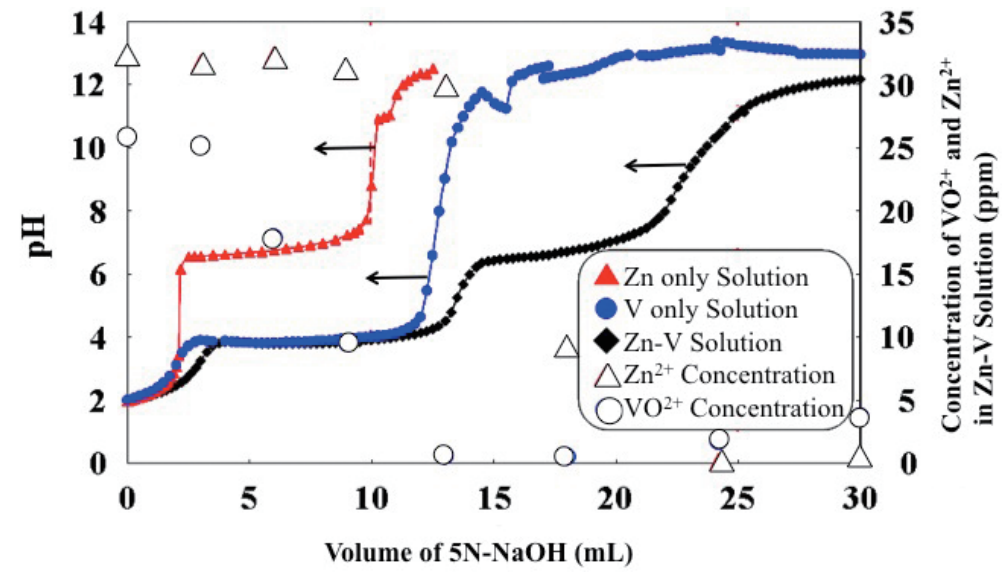

Fig. 5. $\mathrm{pH}$ titration curves of $\mathrm{Zn}-\mathrm{V}$ solution and concentration of $\mathrm{VO}^{2+}$ and $\mathrm{Zn}^{2+}$ in $\mathrm{Zn}-\mathrm{V}$ solution. 
ら得られた $\mathrm{pH}$ 滴定曲線を単純に重ね合わせた結果となっ た。この $\mathrm{pH}$ 上昇が停滞し始めた值は，それぞれの金属酸化 物の溶解度積より求めた $\mathrm{V}_{2} \mathrm{O}_{4}, \mathrm{Zn}(\mathrm{OH})_{2}$ 生成の臨界 $\mathrm{pH}$ の 理論值に近い值となった。このように, 金属酸化物生成の臨 界 $\mathrm{pH}$ はVの方が $\mathrm{Zn} よ り も$ 低いため, 陰極界面では $\mathrm{V}_{2} \mathrm{O}_{4}$ が 優先して形成されると考えられる。Fig.5には, $\mathrm{Zn}^{2+}$ と $\mathrm{VO}^{2+}$ をともに含む溶液に $\mathrm{NaOH}$ 溶液を滴定した際の, 溶液中の $\mathrm{Zn}^{2+}$ と $\mathrm{VO}^{2+}$ の濃度も併せて示す。最初に $\mathrm{pH}$ の上昇が停滞 した $\mathrm{pH} 4$ 付近では, $\mathrm{VO}^{2+}$ イオンのみの濃度が低下し，次に $\mathrm{pH}$ の上昇が停滞した $\mathrm{pH} 6.5$ 付近では $\mathrm{Zn}^{2+}$ の濃度が低下して おり，それぞれの $\mathrm{pH} て ゙ \mathrm{~V}_{2} \mathrm{O}_{4}$ と $\mathrm{Zn}(\mathrm{OH})_{2}$ の沈殿が生じてい ることを裏付けている。なお， $\mathrm{V}_{2} \mathrm{O}_{4}$ の沈殿が生じている時 には溶液中の $\mathrm{Zn}^{2+}$ 濃度はほとんど変化しておらず, $\mathrm{Zn}^{2+}$ が $\mathrm{V}_{2} \mathrm{O}_{4}$ と共沈するような現象は特に認められなかった。

$\mathrm{VO}^{2+}, \mathrm{Zn}^{2+}$ を含む溶液打よび $\mathrm{Zn}^{2+}$ のみを含む静止溶液か ら電析の際, 微小 $\mathrm{Sb}$ 電極法により陰極界面の $\mathrm{pH}$ 直接測 定した。Fig.6に電流密度 $200 \mathrm{~A} / \mathrm{m}^{2}$ で電析した際の陰極近 傍の $\mathrm{pH}$ を示す。陰極表面の $\mathrm{pH}$ は, $\mathrm{Zn}^{2+}$ のみを含む溶液で は, 浴本体よりかなり高い 5.3 まで上昇しているのに対し て, $\mathrm{VO}^{2+}, \mathrm{Zn}^{2+}$ を含む溶液では, 3.8 までしか上昇しなかっ た。 $\mathrm{Zn}^{2+}$ のみを含む溶液では, 電解時の水素発生により $\mathrm{Zn}$ $(\mathrm{OH})_{2}$ 生成の臨界 $\mathrm{pH}$ まで $\mathrm{pH}$ が上昇していると考えられ る。それに対して, $\mathrm{VO}^{2+}, \mathrm{Zn}^{2+}$ 含む溶液では $\mathrm{Zn}(\mathrm{OH})_{2}$ 生 成の臨界 $\mathrm{pH}$ より低い $\mathrm{pH}$ でその上昇が停滞した。これは, $\mathrm{pH} 4$ 付近での $\mathrm{VO}^{2+}$ の加水分解反応による緩衝作用が生じ るためと考えられる。以上の結果より, $\mathrm{VO}^{2+}, \mathrm{Zn}^{2+}$ を含む 溶液からの電析では, 水素発生により陰極表面の $\mathrm{pH}$ が上 昇するものの $\mathrm{V}_{2} \mathrm{O}_{4}$ 形成による緩衝作用のため, $\mathrm{Zn}(\mathrm{OH})_{2}$ 生成の臨界 $\mathrm{pH}$ までは $\mathrm{pH}$ が上昇せず，陰極界面では $\mathrm{V}_{2} \mathrm{O}_{4}$ の みが形成されると考えられる。 $\mathrm{Zn}^{2+}$ は, $\mathrm{Zn}(\mathrm{OH})_{2}$ を経由し ないで $\mathrm{V}_{2} \mathrm{O}_{4}$ 層を通過して $\mathrm{Zn} に$ に還元され，その際に $\mathrm{V}_{2} \mathrm{O}_{4}$ を 電析膜に取り込むと推察される。

\section{$3 \cdot 3$ 電析膜の構造}

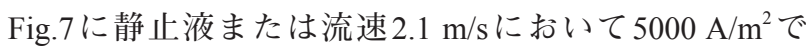
電析させた純 Zn 打よびZn-V酸化物の SEM 観察像を示す。

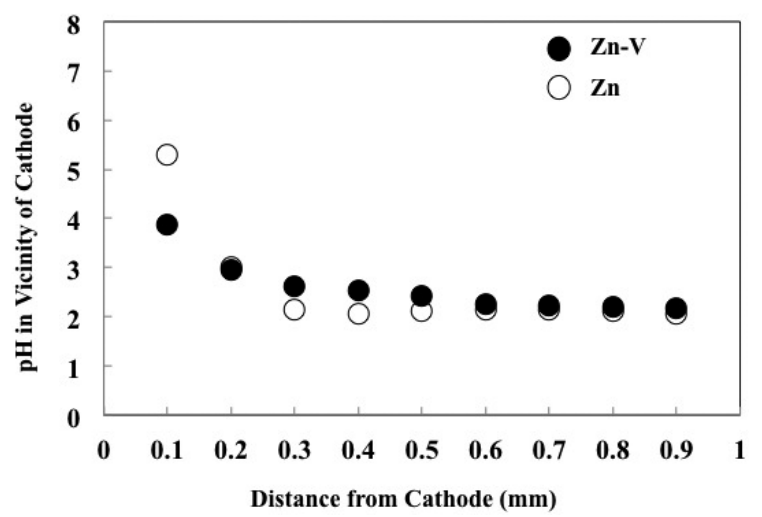

Fig. 6. $\mathrm{pH}$ profiles in the vicinity of cathode during $\mathrm{Zn}-\mathrm{V}$ and Zn deposition.
静止液または流速 $2.1 \mathrm{~m} / \mathrm{s}$ から得られた純 $\mathrm{Zn}$ の電析膜 $(\mathrm{a}$, c) では六方稠密晶である $\mathrm{Zn}$ の板状結晶が大きく成長して 積層して抢り，その板状結晶のエッジ部が明瞭に認められ た。一方, 静止液または流速 $2.1 \mathrm{~m} / \mathrm{s}$ から得られた $\mathrm{V}$ 含有 した電析膜 $(b, d)$ では, Zn 板状結晶の隙間部に平滑な結晶 （b）または粒状の結晶 (d) が埋まっており, 明瞭な Znの板 状結晶は見られなかった。

Fig.8に流速 1.1，2.1，4.2 m/sに打いて $5000 \mathrm{~A} / \mathrm{m}^{2}$ で電析さ せた Zn-V酸化物のEPMA 観察像を示す。流速 $1.1 \mathrm{~m} / \mathrm{s}$ から 得られた $\mathrm{V}$ 含有率 $7.3 \mathrm{mass} \%$ の電析膜の反射電子線像 (a) および $\mathrm{Zn}, \mathrm{V}$ の特性 X線像 $(\mathrm{b}, \mathrm{c})$ では Zn 濃度の高い箇所 ではVの濃度が低く, Zn 濃度の低い箇所ではV の濃度が高 くなっており，VはZn板状結晶の境界部に高濃度で存在し ていることが分かった。また，Oの偏析が見られ (d)，Oの 濃度が高い箇所は, Vの濃度も高くなっており (c), Vが酸 化物として共析していることを裏付けている。流速 $2.1 \mathrm{~m} /$ sに打いて得られた電析膜に打いても, VはZn濃度の低い 箇所すなわち $\mathrm{Zn}$ 板状結晶の境界部に高濃度で存在してい るが $(\mathrm{g})$, その分布状態は, 流速 $1.1 \mathrm{~m} / \mathrm{s}$ からのものに比べ 均一となった。Vは $\mathrm{Zn}$ 板状結晶の境界部に高濃度で存在し ていることから Fig.7 (d) のSEM像に見られたZn板状結晶 隙間部の結晶はV V酸化物であると考えられる。更に流速を $4.2 \mathrm{~m} / \mathrm{s}$ に増加させると, V含有率は 1.8 mass\%まで低下し たもののVの分布状態は，更に均一になった。擋拌を行う ことにより $\mathrm{V}$ の分布が均一になっていることから, $\mathrm{VO}^{2+}$ イ オンの加水分解反応が擋找により陰極界面でより均一に生 じていることが推察される。

Fig.9に流速 $2.1 \mathrm{~m} / \mathrm{s}$ に打いて各種電流密度で電析させ た純Znの結晶配向性を示す。何れの電流密度においても $\{10 \overline{1} 3\}$ 面に優先配向しており，また $\{0001\}$ 面への配向も 比較的強い。(1013) 面は他の結晶面に比べ, $\mathrm{Zn}$ 六方稠密晶 の基底面 (0001) 面に対する傾斜が小さい。すなわち, 電析
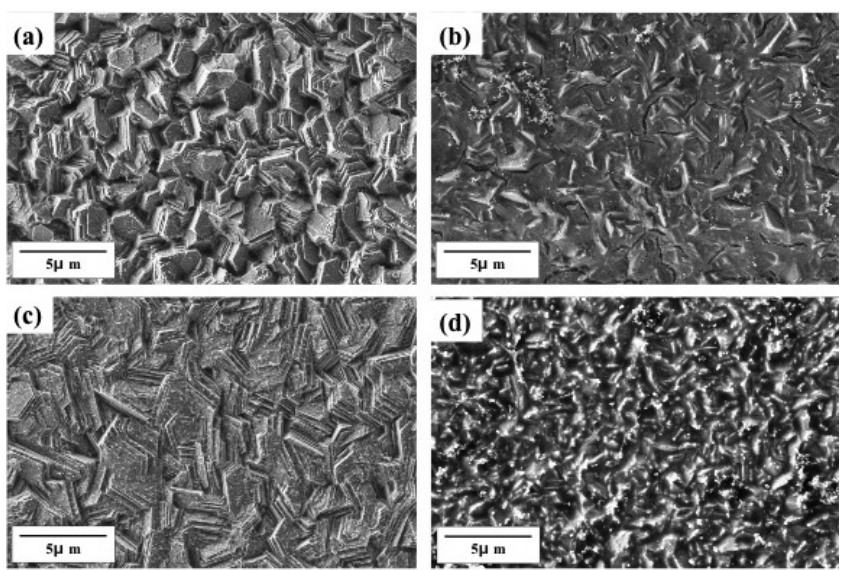
(a) V-free, Non-agitation
(b) $15 \mathrm{mass} \% \mathrm{~V}$, Non-agitation
(c) V-free, $2.1 \mathrm{~m} / \mathrm{s}$
(d) $2 \mathrm{mass} \% \mathrm{~V}, 2.1 \mathrm{~m} / \mathrm{s}$

Fig. 7. SEM images of deposits obtained at $5000 \mathrm{~A} / \mathrm{m}^{2}$ from the solutions with and without $\mathrm{VO}^{2+}$ ions. 


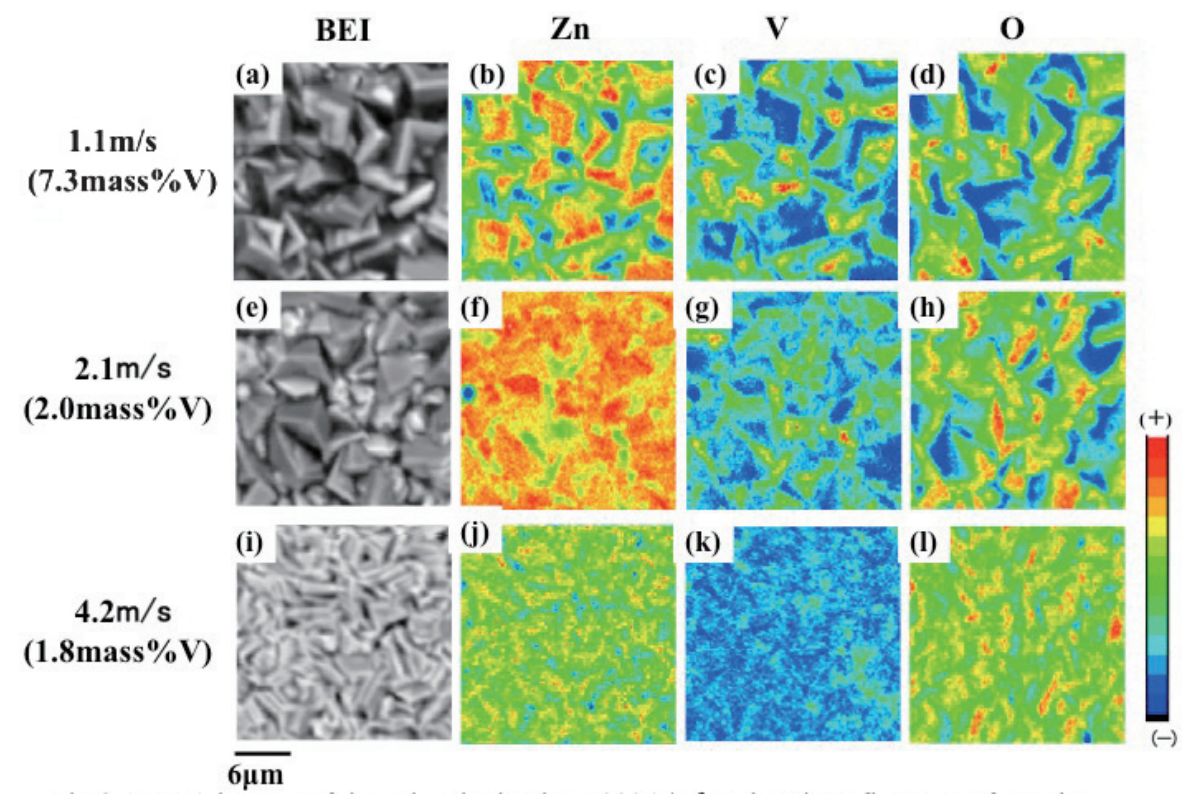

Fig. 8. EPMA images of deposits obtained at $5000 \mathrm{~A} / \mathrm{m}^{2}$ and various flow rates from the solution containing $\mathrm{VO}^{2+}$ ions.

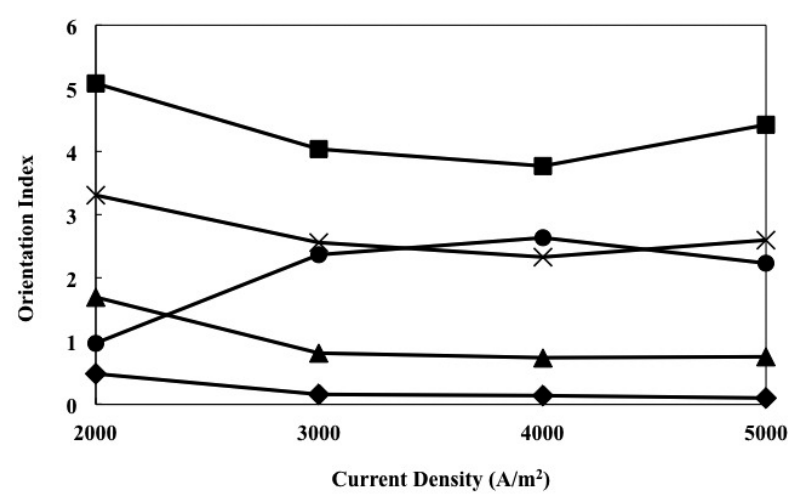

Fig. 9. Crystal orientation of $\mathrm{Zn}$ deposited at flow rate of 2.1 $\mathrm{m} / \mathrm{s}$ and various current densities. $[\bullet(0002), \boldsymbol{\Delta}(10 \overline{1} 2)$,

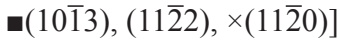

$\mathrm{Znが}\{10 \overline{1} 3\}$ 面に優先配向するということは, Zn板状結晶 の基底面が鋼板に対して平行に近い状態になっていること を意味しており, Fig.6 (c) に示すSEM観察像の結果と対 応している。

Fig.10に流速 $2.1 \mathrm{~m} / \mathrm{s}$ に打いて各種電流密度で電析させた $\mathrm{Zn}-\mathrm{V}$ 酸化物の $\mathrm{Zn}$ の結晶配向性を示す。何れの電流密度に おいても $\{11 \overline{2} 2\}$ 面に優先配向して扬り, Fig.9に示す純 Zn の場合に比べて，\{1013 $\}$ ，\{0001\} 面への配向が減少した。 これは $\mathrm{Zn}$ 板状結晶の基底面が鋼板に対して傾斜して成長 していることを示しており，共析しするV酸化物が $\{0001\}$ 面への配向となる Znの沿面成長を抑制していることが考 えられる。

Fig.11に流速 $2.1 \mathrm{~m} / \mathrm{s}$ に打いて $5000 \mathrm{~A} / \mathrm{m}^{2} て ゙$ 電析させた $\mathrm{Zn}-\mathrm{V}$ 酸化物打よびZnの断面 SEM 観察像を示す。Zn-V酸化 物（a）の最表面には, 純 Zn (b) には見られない薄い膜状の 層が観察された。この薄い層は周辺の組織に比べ黒いこと

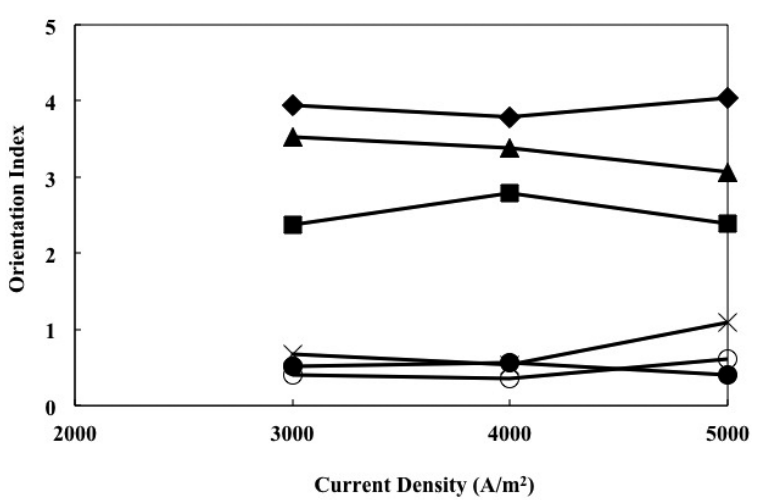

Fig. 10. Crystal orientation of $\mathrm{Zn}$ in $\mathrm{Zn}-\mathrm{V}$ oxide deposited at flow rate of $2.1 \mathrm{~m} / \mathrm{s}$ and various current densities. $[\bullet(0002), \circ(10 \overline{1} 0), \boldsymbol{\Delta}(10 \overline{1} 2), \boldsymbol{\square}(10 \overline{1} 3), \diamond(11 \overline{2} 2)$, $\times(11 \overline{2} 0)]$

から，周辺の組織より軽いことを示しており，V酸化物と 予想された。それを確認するために, Zn-V酸化物 (a) の最 表面を断面側から EDXにより点分析した。

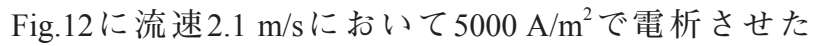
$\mathrm{Zn}-\mathrm{V}$ 酸化物の最表面のEDX スペクトルを示す。Vが検出 され抢り，電析膜の表面にはV 酸化物が存在していること が確認された。なお, 電析膜の膜厚方向の中央部, 下部等 の表面以外の箇所に打いても EDXの点分析を行ったが V は検出されなかった。この結果より, $\mathrm{V}$ 酸化物は電析膜の 表面に濃縮していることが分かった。V酸化物が表面に濃 縮する機構については現状不明であり, 更なる検討が必要 である。

\section{$3 \cdot 4$ 電析膜の分極特性}

Fig. 13 に $3 \% \mathrm{NaCl}$ 水溶液中に打ける Zn- 2.1 mass $\% \mathrm{~V}$ 酸化 物および純Zn電析膜の分極曲線を示す。腐食電位は, Zn2.1 mass\%V 酸化物の方が純 Znに比べ貴であった。また，ア 


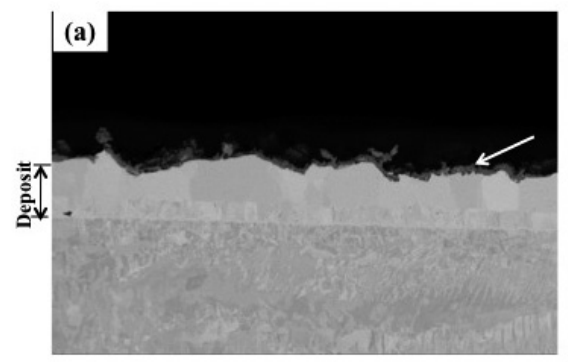

(a) $\mathrm{Zn}-\mathrm{V}$ oxide $\quad$ (b) $\mathrm{Zn}$

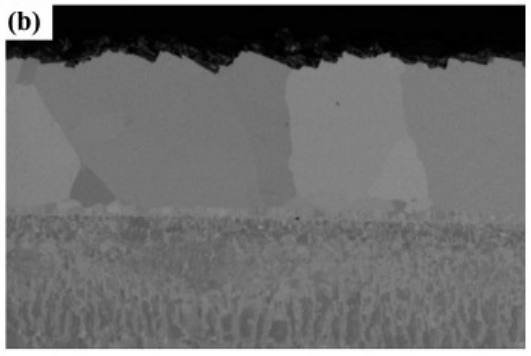

$\underline{2 \mu \mathrm{m}}$

Fig. 11. SEM images of cross section of deposits obtained at $5000 \mathrm{~A} / \mathrm{m}^{2}$ and $2.1 \mathrm{~m} / \mathrm{s}$ from the solutions with and without $\mathrm{VO}^{2+}$ ions.

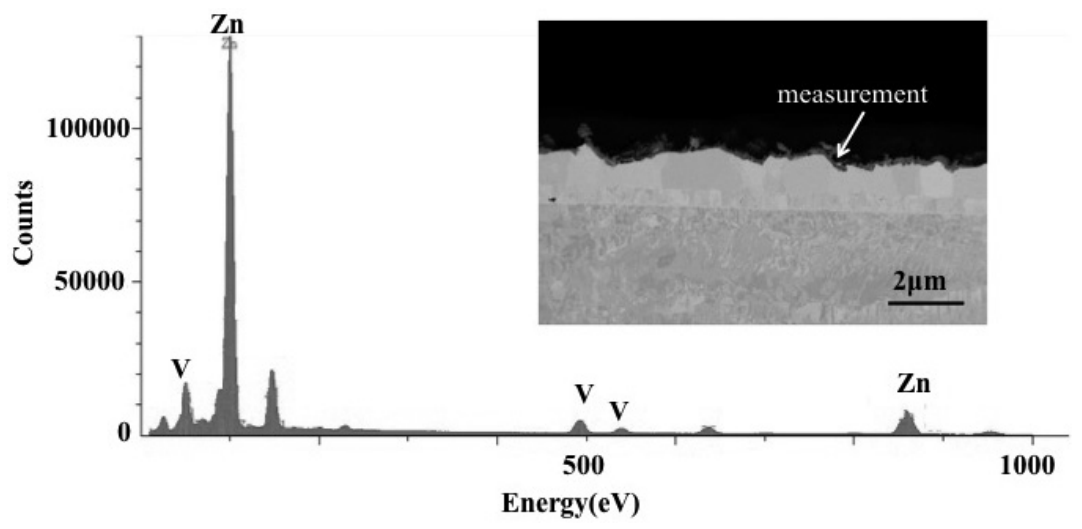

Fig. 12. EDX spectrum of cross section of deposits obtained at $5000 \mathrm{~A} / \mathrm{m}^{2}$ and $2.1 \mathrm{~m} / \mathrm{s}$ from the solutions containing $\mathrm{VO}^{2+}$ ions.

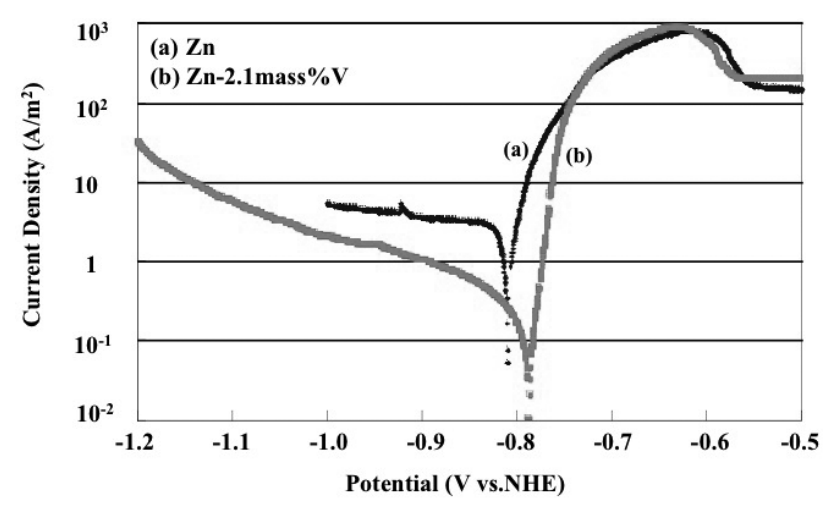

Fig. 13. Polarization curves of $\mathrm{Zn}-\mathrm{V}$ oxide composite in $3 \%$ $\mathrm{NaCl}$ solution.

ノード反応，カソード反応ともに $\mathrm{Zn}-2.1$ mass $\% \mathrm{~V}$ 酸化物の 方が純 Znに比べ電流密度が低下して打り, その結果, 腐食 電流も Zn-2.1 mass $\% \mathrm{~V}$ 酸化物の方が小さくなった。 $3 \% \mathrm{NaCl}$ 水溶液中に打けるカソード反応は，溶存酸素の還元反応で あるので, $\mathrm{Zn}-2.1 \mathrm{mass} \% \mathrm{~V}$ 酸化物では，酸素の還元反応が 抑制されていると言える。V酸化物が溶液中の溶存酸素の 拡散障壁となっている可能性も考えられる。

種々の流速下で得られた $\mathrm{V}$ 含有率の異なる電析膜の腐 食電位を分極曲線より求めた。その結果を Fig.14に示す。 $\mathrm{Zn}-\mathrm{V}$ 酸化物の腐食電位は, 液の流速にかかわらずV含有 率により変化し, $\mathrm{V}$ 含有率が 2 mass $\%$ 以下の領域ではV 酸

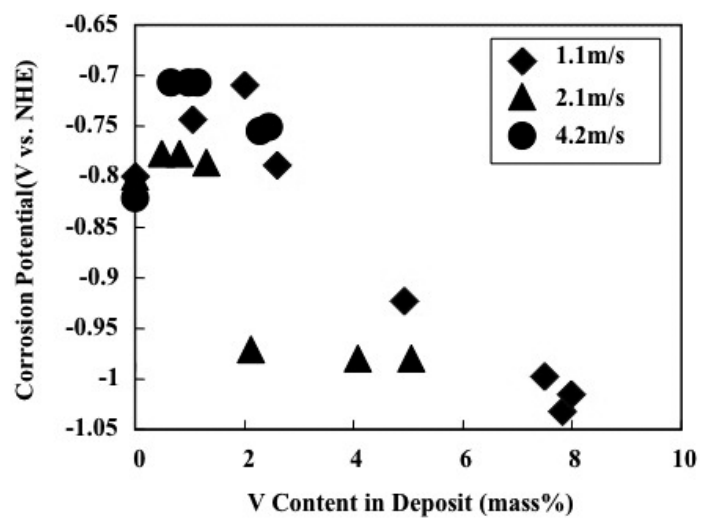

Fig. 14. Relationship between $\mathrm{V}$ content and the corrosion potential of $\mathrm{Zn}-\mathrm{V}$ oxide composite in $3 \% \mathrm{NaCl}$ solution.

化物が共析することにより貴な方に移行したが V含有率が 2 mass\%を越えるとV含有率の増加に伴い卑な方に移行し た。V含有率が 2 mass $\%$ 以下の電析膜ではV酸化物の共析 により Zn 溶解反応のアノード分極曲線が貴に移行してい るため, 腐食電位も貴に移行したと考えられる。これはV 酸化物の導電率が極めて小さいため, 一種のバリヤー効果 を発揮したと考えられる。V含有率が 2 mass\%を越えると 腐食電位が卑になった原因については現状不明であるが， アノード反応が $\mathrm{Zn} \rightarrow \mathrm{Zn}^{2+}+2 \mathrm{e}^{-}$から $\mathrm{Zn}+\mathrm{H}_{2} \mathrm{O} \rightarrow \mathrm{ZnO}+2 \mathrm{H}^{+}$ $+2 \mathrm{e}^{-}$に変化していると仮定すれば, 腐食電位が卑に移行 することが説明できる。 


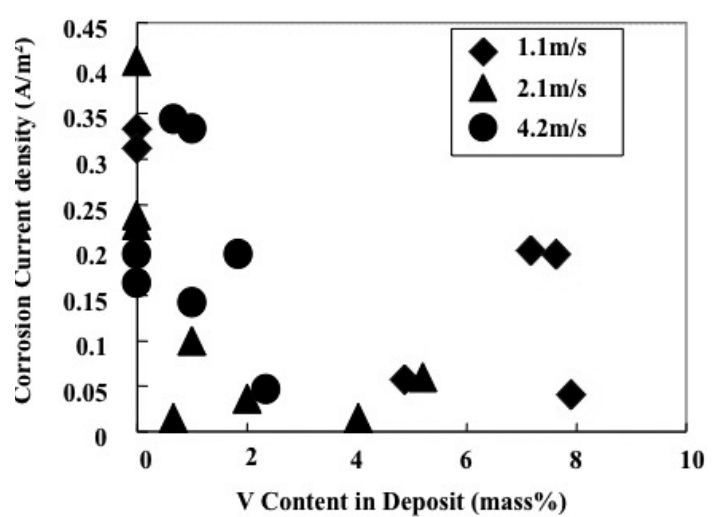

Fig. 15. Relationship between $\mathrm{V}$ content and the corrosion current density of $\mathrm{Zn}-\mathrm{V}$ oxide composite in $3 \% \mathrm{NaCl}$ solution.

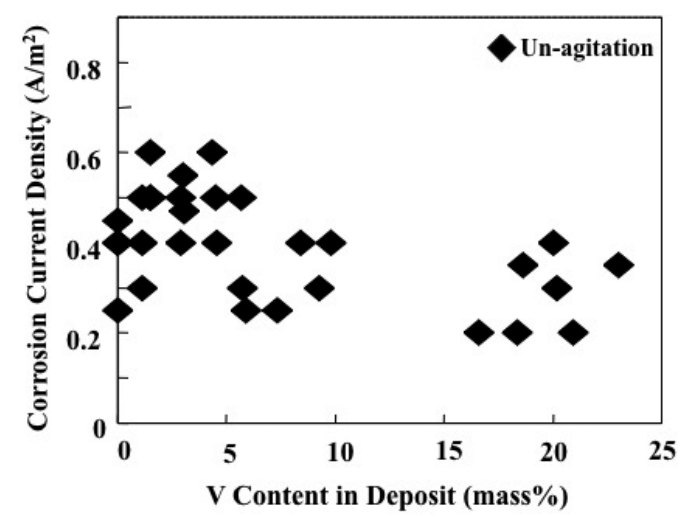

Fig. 16. Relationship between $\mathrm{V}$ content and the corrosion current density of $\mathrm{Zn}-\mathrm{V}$ oxide composite in $3 \% \mathrm{NaCl}$ solution ${ }^{15)}$.

Fig.15に分極曲線より求めた電析膜の腐食電流密度を示 す。電析膜の腐食電流密度と V 含有率の関係にはバラッキ が見られるものの, V含有率が 4 mass\% 以下の領域では, $\mathrm{V}$ 含有率が増加するほど腐食電流密度は低下した。これは, $\mathrm{V}$ 酸化物のバリヤー効果により，アノード反応，カソード 反応が抑制されるためと考えられる。著者らは，静止液か ら得られた電析膜の腐食電流密度にはバラツキが多く, V 含有率と腐食電流密度との間に明確な相関関係が認められ ないことを前報にて報告した ${ }^{15}$ (Fig.16)。Fig.15と Fig.16に 示す腐食電流密度を比較すると, 本研究の電解液を摚找し て得られた電析膜は静止液からの場合に比べその腐食電流 密度が小さくなる傾向が見られた。電析膜のV酸化物の分 布状態は電解液を摚找した方が均一になっていることか ら,V酸化物の均一性が腐食電流密度に影響を及ぼしてい る可能性がある。

\section{4. 結言}

$\mathrm{Zn}^{2+}, \mathrm{VO}^{2+}$ を含む硫酸塩水溶液から高流速摚拌下におい て, Zn-V酸化物複合電析を行い, その電析挙動と得られた 電析膜の構造, 分極特性を調査した結果, 以下のことが明
らかとなった。電析膜のV含有率は, 何れの流速において も電流密度が高くなるほど一旦減少したが, 更に電流密度 が高くなると増加した。流速が速くなるほど, 電析膜のV 含有率と電流密度の関係を示す曲線が高電流密度側にシ フトした。電解液を摚拌すると電析膜の V 含有率は低下し たが, V酸化物の分布はより均一となった。また, 電析膜 断面の EDX点分析より, $\mathrm{V}$ 酸化物は電析膜の表面に濃縮し ていることが分かった。微小 Sb電極法により電析時の陰 極界面の $\mathrm{pH}$ 測定したところ, $\mathrm{V}_{2} \mathrm{O}_{4}$ 生成の臨界 $\mathrm{pH}$ に近い $\mathrm{pH} 4$ 前後となっていることが分かった。 $3 \% \mathrm{NaCl}$ 水溶液中 に打ける電析膜の分極曲線より, $\mathrm{Zn}-\mathrm{V}$ 酸化物の腐食電位 は, 液の流速にかかわらずV含有率により変化し, $\mathrm{V}$ 含有 率が 2 mass\% 以下の領域ではV 酸化物が共析することによ り貴な方に移行することが分かった。V含有率が 4 mass\% 以下の領域では, $\mathrm{v}$ 含有率が増加するほど電析膜の腐食電 流密度は低下した。電解液を擋拌して得られた電析膜は静 止液からの場合に比べその腐食電流密度が小さくなる傾向 が見られた。

\section{文献}

1 ) K.Nishimura, H.Shindo, H.Nomura and K.Kato: Tetsu-to-Hagané, 89(2003), 174

2 ) K.Nishimura amd H.Shindo: CAMP-ISIJ, 9(1996), 1278.

3 ) K.Nishimura, S.Shimazu, H.Nomura, H.Shindo, K.Asai and H.Matsuda: CAMP-ISIJ, 16(2003), 1507.

4 ) J.Kawafuku, J.Katoh, M.Toyama, H.Nishimoto, K.Ikeda and H.Satoh: Tetsu-to-Hagané, 77(1991), 995.

5 ) 佐藤廣士：第 $138 \cdot 139$ 回西山記念技術講座，表面処理技術の 進歩と今後の動向，日本鉄鋼協会編，東京，(1991), 101.

6 ) H.Nishimoto: CAMP-ISIJ, 1(1988), 1631.

7 ) K.Ikeda: CAMP-ISIJ, 1(1988), 1632.

8 ) Y.Morimoto, M.Kurosaki, K.Honda, K.Nishimura, A.Takahashi and H.Shindo : Tetsu-to-Hagané, 89(2003), 161.

9 ) T.Shimizu, F.Yoshizaki, Y.Miyoshi and A.Ando: Tetsu-to-Hagané, 89(2003), 166.

10) T.Aoki, Y.Miyoshi and T.Kittaka: Proc. of 3rd Int. Conf. On Zinc and Zinc Alloy Coated Steel Sheet (GALVATECH'95), ISS, Walendale, PA, (1995), 463.

11) S.Ando and M.Sagiyama: J. Surf. Finish. Soc. Jpn., 52 (2001), 687.

12) T.Akiyama, L.Lanying, H.Fukushima, K.Higashi, T.Watanabe and T.Hara: Tetsu-to-Hagané, 74(1988), 130

13) T.Adaniya, H.Fukushima and K.Higashi: Tetsu-to-Hagané, 69(1983), 959.

14) T.Tsuda, A.Shibuya, M.Nishihara, K.Yamada, M.Kato and K.Yanagi: Tetsu-to-Hagané, 72(1986), 946.

15) H.Nakano, S.Oue, D.Kozaki, S.Kobayashi and H.Fukushima: Tetsuto-Hagané, 93(2007), 703.

16) K.S.Willson and J.A.Rogers: Tech. Proc. Amer. Electroplaters Soc., 51(1964), 92.

17) H.Fukushima, T.Akiyama, J.Lee, M.Yamaguchi and K.Higashi: J. Met. Finish. Soc. Jpn., 33(1982), 574.

18) M.Pourbaix: Atlas of Electrochemical Equilibria, Pergamon Press, (1966), 234.

19) Allen J.Bard 著, 松田好晴, 小倉興太郎 共訳: 溶液内イオン平衡, 化学同人, 京都, (1993), 198. 